\title{
Binding-protein-dependent Glucose Transport by Agrobacterium radiobacter Grown in Glucose-limited Continuous Culture
}

\author{
By ALEX CORNISH, JACQUELINE A. GREENWOOD \\ AND COLIN W. JONES* \\ Department of Biochemistry, University of Leicester, Leicester LE1 7RH, UK
}

(Received 15 June 1988; revised 27 July 1988)

Agrobacterium radiobacter NCIB 11883 was grown in glucose-limited continuous culture at low dilution rate. Whole cells transported glucose using an energy-dependent mechanism which exhibited an accumulation ratio $>2000$. Three major periplasmic proteins were purified and their potential role as glucose-binding proteins (GBP) were investigated using equilibrium dialysis. Two of these, GBP1 $\left(M_{\mathrm{r}} 36500\right)$ and GBP2 $\left(M_{\mathrm{r}} 33500\right)$, bound D-glucose with high affinity $\left(K_{\mathrm{D}} 0.23\right.$ and $0.07 \mu \mathrm{M}$ respectively), whereas the third protein $\left(M_{\mathrm{r}} 30500\right)$ showed no binding ability. Competition experiments using various analogues showed that those which differed from glucose at C-6 (e.g. 6-chloro-6-deoxy-D-glucose and 6-deoxy-D-glucose) variably decreased the binding of glucose to both GBP1 and GBP2, whereas those which differed at C-4 (e.g. D-galactose) were only effective with GBP1. The rate of glucose uptake and the concentration of the glucose-binding proteins increased in parallel during prolonged growth under glucose-limitation due to the emergence of new strains in which GBP1 (e.g. strain AR18) or GBP2 (e.g. strain AR9), but not both, was hyperproduced and accounted for at least $27 \%$ of the total cell protein. It is concluded that $A$. radiobacter synthesizes two distinct periplasmic binding proteins which are involved in glucose transport, and that these proteins are maximally derepressed during growth under glucose limitation.

\section{INTRODUCTION}

Most bacteria capable of growing anaerobically possess phosphotransferase systems (PTS) that catalyse the uptake and concomitant phosphorylation of glucose at the expense of phosphoenolpyruvate (Postma, 1986). By contrast, this type of glucose uptake system appears to be absent from the very limited number of aerobic bacteria in which glucose transport has been studied, although a fructose-specific PTS has been identified in Pseudomonas aeruginosa (Durham \& Phibbs, 1982).

Two alternative routes for glucose uptake, both involving periplasmic proteins, have been identified in $P$. aeruginosa. During growth in continuous culture under glucose-excess, oxygensufficient conditions this organism does not take up glucose directly but produces two periplasmic enzymes, glucose dehydrogenase and gluconate dehydrogenase, that sequentially oxidize glucose to gluconate and 2-ketogluconate which are then taken up via specific transport systems (Midgley \& Dawes, 1973; Roberts et al., 1973; Whiting et al, 1976). This extracellular oxidation system is repressed during glucose-limited growth (Whiting et al., 1976) and glucose is taken up directly via a high-affinity transport system (Midgley \& Dawes, 1973). The latter involves a periplasmic, glucose-binding protein (Stinson et al., 1977) and thus appears to be analogous to the binding-protein-dependent transport systems for certain sugars, amino acids and inorganic ions that have been investigated in detail in enteric bacteria (Ames, 1986).

\footnotetext{
Abbreviations: FCCP, carbonyl cyanide p-trifluoromethoxyphenylhydrazone; FPLC, fast protein liquid chromatography; GBP, glucose-binding protein; PQQ, pyrroloquinoline quinone.
} 
Agrobacterium radiobacter NCIB 11883, a recently isolated aerobic bacterium (Linton et al., 1987), is unable to metabolize glucose using the indirect, oxidative route since it produces a nonfunctional, apoenzyme form of glucose dehydrogenase that lacks the PQQ co-factor (Linton et al., 1986; Cornish et al., 1987). This paper describes investigations into the mechanism via which $\boldsymbol{A}$. radiobacter takes up glucose directly during growth in glucose-limited continuous culture.

\section{METHODS}

Organism and growth conditions. Agrobacterium radiobacter NCIB 11883 was grown at $30^{\circ} \mathrm{C}$ in continuous culture $\left(D=0.045 \mathrm{~h}^{-1}\right)$ under glucose limitation using a chemically defined medium (Linton et al., 1987) supplemented with glucose $\left(4 \mathrm{~g}^{-1}\right)$, ammonium sulphate $\left(3 \mathrm{~g} \mathrm{l}^{-1}\right)$ and nitrilotriacetic acid $\left(0 \cdot 142 \mathrm{~g}^{-1}\right)$. The organism was grown in an LH series 500 chemostat of 2 litre working volume at a steady-state biomass density of $2 \cdot 1 \mathrm{~g}$ dry wt $1^{-1}$.

Preparation of cell suspensions. Cell suspensions were prepared using $20 \mathrm{mM}-\mathrm{HEPES} / \mathrm{KOH}$ buffer, $\mathrm{pH} 7 \cdot 0$, as described previously (Cornish et al., 1987).

Measurement of glucose uptake. Rates of glucose uptake were determined by measuring the incorporation of D- $-U^{-14}$ Clglucose into whole cells over a period of $60 \mathrm{~s}$. Assays were done in an open-topped Rank oxygen

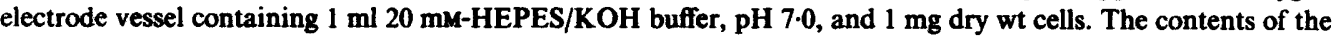
vessel were maintained at $30^{\circ} \mathrm{C}$ and mixed continuously using a magnetic stirrer. Assays were started by adding D-fU-14 Clglucose [ $2 \mathrm{mCi} \mathrm{mmol}^{-1}\left(74 \mathrm{MBq} \mathrm{mmol}^{-1} ; 0.5 \mu \mathrm{Ci}(18.5 \mathrm{kBq})\right]$ to give a final concentration of $250 \mu \mathrm{M}$. Samples $(50 \mu \mathrm{l})$ of the reaction mixture were withdrawn at $15 \mathrm{~s}$ intervals and the cells were collected on nitrocellulose filters of $0.45 \mu \mathrm{m}$ pore size $(2.5 \mathrm{~cm}$ diameter; Sartorius) by means of a manifold connected to a vacuum line. The filters were washed immediately using $3 \mathrm{ml} 20 \mathrm{mM}-\mathrm{HEPES}$, pH 7.0, dried under an infra-red lamp and then immersed in $5 \mathrm{ml}$ Optiscint $\mathrm{T}$ scintillant (LKB). The extent of incorporation of $\left[{ }^{14} \mathrm{C}\right] \mathrm{glucose}$ into the cells was determined by counting the radioactivity on the filters using a Hewlett Packard Tri-Carb liquid scintillation counter (80-85\% efficiency). Glucose uptake rates were measured in triplicate for each batch of cells and the standard errors never exceeded $10 \%$ of the mean values.

In order to measure glucose uptake rates at low concentrations of substrate $(1-5 \mu \mathrm{M})$ the cell density was reduced to $0.01 \mathrm{mg} \mathrm{ml}^{-1}$, the specific activity of the $\left[^{14} \mathrm{Clglucose}\right.$ was increased to $84 \mathrm{mCi} \mathrm{mmol}^{-1}\left(3.2 \mathrm{GBq} \mathrm{mmol}^{-1}\right)$ and the rate of incorporation of ${ }^{14} \mathrm{C}$-label into cells was measured over a period of $35 \mathrm{~s}$. These modifications ensured that less than $20 \%$ of the glucose was consumed during the incubation.

The capacity of $A$. radiobacter to accumulate glucose was determined by incubating cell suspension ( $1 \mathrm{mg}$ dry wt $\left.\mathrm{ml}^{-1}\right)$ with $\mathrm{D}-\left[\mathrm{U}^{-14} \mathrm{Clglucose}^{2} 84 \mathrm{mCi} \mathrm{mmol}^{-1}\left(3.2 \mathrm{GBq} \mathrm{mmol}^{-1}\right) ; 20 \mu \mathrm{M}\right.$ initial concentration]. Samples $(100 \mu \mathrm{l})$ of the suspension were withdrawn $10 \mathrm{~s}$ after adding the glucose and the cells were collected on nitrocellulose filters $(0.45 \mu \mathrm{m}$ pore size) using vacuum filtration. The filters were washed immediately using $3 \mathrm{ml}$ buffer and immersed in $20 \mathrm{ml}$ boiling water. Aqueous extracts prepared from four filters were pooled, lyophilized and the residue was dissolved in $2 \mathrm{ml}$ water. The glucose content of the cells was determined using liquid scintillation counting following separation of $\left[{ }^{14} \mathrm{C}\right.$ glucose from other labelled metabolites present in the extracts using paper chromatography (propan-2-ol/ammonia/water; $6: 3: 1$, by vol.). Samples of the filtrate plus washings were also counted in order to determine the extracellular concentration of glucose at the time of sampling.

The substrate specificity of the transport system was investigated by determining the extent to which unlabelled glucose analogues $(10 \mathrm{~mm})$ reduced the rate of uptake of $\left[{ }^{14} \mathrm{Clglucose}(250 \mu \mathrm{M})\right.$. Cell suspensions were incubated with analogues for $5 \mathrm{~s}$ prior to addition of $\left[{ }^{14} \mathrm{C}\right]$ glucose. Where indicated, FCCP $(2 \mu \mathrm{l}$ of a $10 \mathrm{mM}$ stock solution in dimethylformamide) was added to the cell suspension $10 \mathrm{~s}$ before the glucose; uptake was not affected by the presence of the solvent alone.

Osmotic shock. This was done essentially as described by Neu \& Heppel (1965) except that plasmolysed cells were shocked using ice-cold $20 \mathrm{~mm}$-bis-Tris buffer, pH 6.8, instead of distilled water.

FPLC. Periplasmic proteins released by osmotic shock were separated using anion-exchange FPLC. Samples of shock fluid (10-15 ml containing 5-10 mg protein) were passed through an acrodisc filter of $0.45 \mu \mathrm{m}$ pore-size filter (Gelman) in order to remove particulate material, and the filtrate was loaded onto a Mono- $Q$ column (Pharmacia) equilibrated with $20 \mathrm{mu}$-bis-Tris, pH 6.8. All of the periplasmic proteins bound to the column under these conditions and were eluted in turn using a linear $\mathrm{KCl}$ gradient (the $\mathrm{KCl}$ concentration was increased from 0-200 mu over $20 \mathrm{~min}$ using a flow rate of $1 \mathrm{ml} \mathrm{min}-1$ ). The protein content of the effluent was monitored at $280 \mathrm{~nm}$. The three most abundant periplasmic proteins $\left(M_{\mathrm{r}}=36500,33500\right.$ and 30500 , which were eluted using $140 \mathrm{~mm}, 60 \mathrm{~mm}$ and $90 \mathrm{mM} \mathrm{KCl}$ respectively) were virtually homogeneous after this purfication step ( $>95 \%$ pure as judged by SDS-PAGE analysis) and were stored at $-20^{\circ} \mathrm{C}$ until required.

Gel-filtration FPLC was used to estimate the sizes of the purified proteins. Samples of pure proteins $(200 \mu l$, containing approximately $200 \mu \mathrm{g}$ protein) were loaded onto a Superose 12 column (Pharmacia) equilibrated with 
20 mM-bis-Tris, pH 6.8, and were eluted using a flow rate of $0.3 \mathrm{ml} \mathrm{min}^{-1}$. The protein content of the effluent was monitored at $280 \mathrm{~nm}$ and the retention time for each protein was noted. The column was calibrated using a mixture of the following proteins: bovine albumin, $M_{t} 132000$ (dimer) and 66000 (monomer); egg albumin, 45000; carbonic anhydrase, 29000; and horse-heart cytochrome $c, 12400$.

$S D S-P A G E$. Discontinuous electrophoresis of proteins was done using $12 \%(w / v)$ acrylamide gels according to the method of Laemmli (1970). Whole cells of A. radiobacter were boiled for $4 \mathrm{~min}$ is dissolving buffer (Laemmli, 1970) and a volume containing $20 \mu \mathrm{g}$ protein was loaded into each gel track. The gels were stained for protein with Kenacid Blue R (Weber \& Osborn, 1975), then destained and scanned at $633 \mathrm{~nm}$ using an LKB laser densitometer linked to a recording integrator. The following proteins were used as standards: lactalbumin, $M_{\mathrm{r}} 14200$; trypsin inhibitor, 20100; trypsinogen, 24000; carbonic anhydrase, 29000; glyceraldehyde-3-phosphate dehydrogenase, 36000; egg albumin, 45000; and bovine albumin, 66000 .

Determination of binding constants using equilibrium dialysis. This was done at $4{ }^{\circ} \mathrm{C}$ using an eight-cell rotating module (Hoefer Scientific Instruments). Each cell was divided into two chambers of $0.5 \mathrm{ml}$ volume using a dialysis membrane $\left(M_{\mathrm{r}}\right.$ cut-off $\left.=6000-8000\right)$. Pure protein $(0.5 \mathrm{nmol})$ was added to one chamber of each cell in $0.3 \mathrm{ml}$ bisTris, pH 6.8. Each of the opposing chambers was loaded with $0.3 \mathrm{ml}$ bis-Tris $(0.3 \mathrm{ml})$ containing $\mathrm{D}-\left[\mathrm{U}-{ }^{14} \mathrm{Clglucose}\right.$ [270 $\mathrm{mCi} \mathrm{mmol}^{-1}\left(10 \mathrm{GBq} \mathrm{mmol}{ }^{-1}\right)$ ], the concentration of which was varied over an appropriate range. The module was rotated at 10 r.p.m. for $30 \mathrm{~h}$ (by which time equilibrium had been attained) and samples $(50 \mu \mathrm{l})$ were taken in triplicate from each chamber and counted in $3 \mathrm{ml}$ Optiphase $\mathrm{T}$ (LKB). The data were analysed according to the method of Scatchard (1949).

The capacity of glucose analogues to reduce the extent of binding of $\mathrm{D}-\left[\mathrm{U}-{ }^{14} \mathrm{C}\right] \mathrm{glucose}$ to pure proteins was determined by modifying the assay procedure as follows. One chamber of each cell contained $0.5 \mathrm{nmol}$ pure protein in $0.3 \mathrm{ml}$ bis-Tris, $\mathrm{pH} 6.8$, and the other chamber was loaded with $0.3 \mathrm{ml}$ buffer containing $3 \mathrm{nmol}$ D- $\left[\mathrm{U}^{-14} \mathrm{C}\right]$ glucose $\left[85 \mathrm{mCi} \mathrm{mmol}^{-1}\left(3.2 \mathrm{GBq} \mathrm{mmol}^{-1}\right)\right]$ plus $120 \mathrm{nmol}$ of an unlabelled glucose analogue. The quantity of $\left[{ }^{14} \mathrm{Clglucose}\right.$ that bound to the proteins in the presence and absence of unlabelled glucose analogues was determined after $30 \mathrm{~h}$ incubation.

Pulse labelling. $\left.\mathrm{L}-{ }^{35} \mathrm{~S}\right] \mathrm{Methionine}\left[>800 \mathrm{Ci} \mathrm{mmol}^{-1}\left(30 \mathrm{TBq} \mathrm{mmol}{ }^{-1}\right) ; 50 \mu \mathrm{Ci}(1.85 \mathrm{MBq})\right]$ was added to an exponential phase culture $(50 \mathrm{ml})$ of $A$. radiobacter, followed $10 \mathrm{~min}$ later by unlabelled methionine $(1 \mathrm{~mm})$. Samples $(1.5 \mathrm{ml})$ were taken at $0.5 \mathrm{~h}$ intervals for $5 \mathrm{~h}$, then immediately centrifuged, washed and resuspended in dissolving buffer (Laemmli, 1970) prior to boiling for $4 \mathrm{~min}$. After SDS-PAGE, radiolabelling of major proteins was determined by autoradiography or by scintillation counting of excised bands (Quilter \& Jones, 1984).

Enzyme assays. 6-Phosphogluconate dehydrogenase activity was assayed by the method of Beardsmore $e t$ al. (1982).

Presentation of data. Where appropriate, values have been given as the mean $\pm \mathrm{SBM}$ with the number of independent determinations in parentheses.

Chemicals. $\mathrm{D}-\left[\mathrm{U}-{ }^{14} \mathrm{C}\right] \mathrm{Glucose}\left[270 \mathrm{mCi} \mathrm{mmol}^{-1}\left(10 \mathrm{GBq} \mathrm{mmol}{ }^{-1}\right)\right]$ and $\mathrm{L}-{ }^{35}$ S $]$ methionine $\left[>800 \mathrm{Ci} \mathrm{mmol}^{-1}(30\right.$ $\left.\mathrm{TBq} \mathrm{mmol}^{-1}\right)$ ] was purchased from Amersham. Glucose analogues were obtained from Sigma. Other reagents were purchased from Fisons and were of the highest grade available.

\section{RESULTS}

Whole cell studies on the mechanism of glucose uptake by $A$. radiobacter following growth in continuous culture under glucose limitation at a dilution rate of $0.045 h^{-1}$

The initial rates of glucose uptake measured for five independent glucose-limited cultures yielded a mean value of $55 \pm 3 \mathrm{nmol} \mathrm{min}^{-1}(\mathrm{mg} \mathrm{dry} \mathrm{wt})^{-1}$, identical to the value determined for the rate of glucose uptake in situ at $\mu_{\max }\left(0.35 \mathrm{~h}^{-1}\right)$ and considerably greater than the in situ rate of glucose utilization at $\left.D=0.045 \mathrm{~h}^{-1}\left[9 \mathrm{nmol} \mathrm{min}^{-1} \text { (mg dry wt) }\right)^{-1}\right]$ (Linton et al., 1987). Glucose uptake rates did not increase when cell suspensions were pre-incubated with respiratory substrates (e.g. $10 \mathrm{~mm}$-ethanol or $10 \mathrm{~mm}$-glycerol) prior to the addition of $\left[{ }^{14} \mathrm{C}\right.$ lglucose, indicating that the oxidation of endogenous substrate (Cornish et al., 1987) provided sufficient energy to support the maximum rate of glucose transport. Following the first $60 \mathrm{~s}$ after adding $\left[{ }^{14} \mathrm{C}\right]$ glucose to the cell suspensions, the uptake rate decreased abruptly to a value of approximately $40 \mathrm{nmol} \mathrm{min}{ }^{-1}$ (mg dry wt) ${ }^{-1}$ and probably reflected the rate at which glucose was further metabolized rather than the potential activity of the transport system per se.

For many bacterial sugar transport systems it has proved possible to isolate transport activity from subsequent metabolism, thus enabling the kinetic constants and other important parameters of the uptake system to be determined. This has been accomplished either by measuring the capacity of whole cells to accumulate non-metabolizable, radiolabelled analogues 
of a naturally occurring sugar or by using mutants that are unable to metabolize a given sugar but retain the relevant transport system (see Henderson, 1986). It was not appropriate in the current work to study glucose transport using mutants of $A$. radiobacter defective in glucose metabolism since the primary objective was to identify the mode of transport used during growth under glucose limitation. The possibility of using radiolabelled $\alpha-1-O$-methyl-D-glucose, 3-O-methyl-Dglucose or 2-deoxy-D-glucose (which are the only non-metabolizable, radiolabelled analogues of glucose available from commercial sources) as artificial substrates of the glucose uptake system(s) was considered but, unfortunately, none of the these unlabelled analogues appreciably reduced the rate of $\left[{ }^{14} \mathrm{C}\right.$ lglucose uptake by $A$. radiobacter when they were added at a $40: 1$ molar excess, thus indicating that the organism displays a large preference for the natural substrate (see below).

The assay system used to measure the rate of glucose uptake undoubtedly underestimated the actual rate of transport since some of the $\left[{ }^{14} \mathrm{Clglucose}\right.$ taken up by the cells would have been oxidized to ${ }^{14} \mathrm{CO}_{2}$, This was confirmed by immediately immersing the filters in scintillant (see Henderson, 1986), rather than allowing them to dry under the infra-red lamp; under these conditions the observed rate of glucose uptake was increased by $\leqslant 25 \%$.

Accurate determination of the kinetic parameters (i.e. $K_{\mathrm{m}}$ and $V_{\max }$ ) for glucose transport by $A$. radiobacter was not possible in the presence of further metabolism. However, the rate of glucose uptake did not change when the concentration of $\left[{ }^{14} \mathrm{C}\right]$ glucose used in the assay system was varied over the range $1 \mu \mathrm{M}-1 \mathrm{mM}$, indicating that the $K_{\mathrm{m}}$ for glucose uptake was less than $1 \mu \mathrm{M}$.

Glucose transport was strongly inhibited by the uncoupling agent FCCP (approximately $95 \%$ inhibition at $20 \mu \mathrm{M})$. Unmodified glucose accounted for $70 \%$ of the total radioactivity recovered when cells were incubated with $\left[{ }^{14} \mathrm{C}\right.$ lglucose for $10 \mathrm{~s}$ before being washed rapidly and extracted in boiling water, and an accumulation ratio ([glucosel $]_{\text {in }} /[\text { glucosel }]_{\text {out }}$ ) of 2000-6000 was estimated by assuming an intracellular volume of $1-3 \mu \mathrm{l}(\mathrm{mg} \text { dry } \mathrm{wt})^{-1}$. These results indicated that the organism was capable of taking up glucose actively against a large concentration gradient using a non-phosphotransferase system [since in the latter case the uptake and phosphorylation of glucose would have taken place concomitantly (Postma, 1986)]. A proton symport mechanism was also ruled out since there was no evidence of any alkalinization when glucose was added to suspensions of $A$. radiobacter under strictly anaerobic conditions using the method of Henderson \& Macpherson (1986). The possibility was therefore considered that glucose was being taken up by a system involving a periplasmic binding protein. Bindingprotein-dependent transport systems in enteric bacteria have often been reported to be highly susceptible to osmotic shock procedures that cause the substrate-binding protein to be released from the periplasm, but relatively resistant to inhibition by uncouplers (a variety of evidence suggests that such systems are driven by ATP hydrolysis rather than by the protonmotive force per se, but the mechanism of energy coupling has not been determined unequivocally; see Ames, 1986). The finding that FCCP was a powerful inhibitor of glucose transport in $\boldsymbol{A}$. radiobacter was therefore perfectly compatible with the possibility that a periplasmic binding protein was involved, since an aerobic organism of this type probably depends largely on oxidative phosphorylation rather than substrate-level phosphorylation to produce ATP. In order to confirm the involvement of a binding protein system it was decided to investigate whether $A$. radiobacter did indeed contain periplasmic, glucose-binding proteins during growth under glucose limitation.

\section{Characterization of periplasmic glucose-binding proteins isolated from A. radiobacter following growth under glucose limitation}

As the glucose uptake rates of whole cells of $A$. radiobacter that had been grown under glucose limitation $\left(D=0.045 \mathrm{~h}^{-1}\right)$ were comparable to the glucose uptake rate at $\mu_{\max }$, it was concluded that the glucose uptake system was substantially de-repressed so as to enable the organism to take up glucose at the in situ rate of $9 \mathrm{nmol} \min ^{-1}(\mathrm{mg} \text { dry wt) })^{-1}$, even when the standing concentration of glucose in the chemostat was very low. These observations suggested that it might be possible to identify components of the glucose transport system by using SDS-PAGE to 
(a)

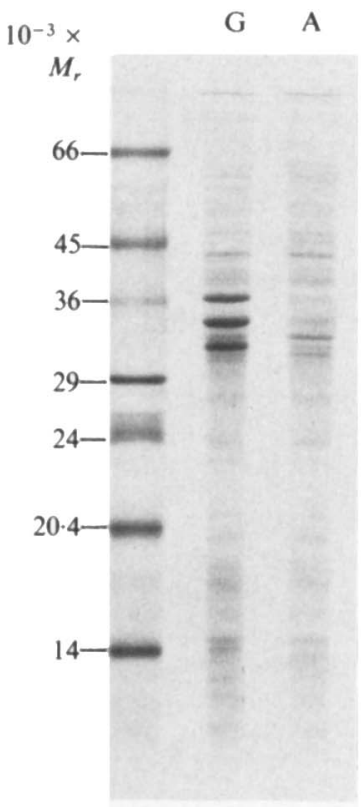

(b)

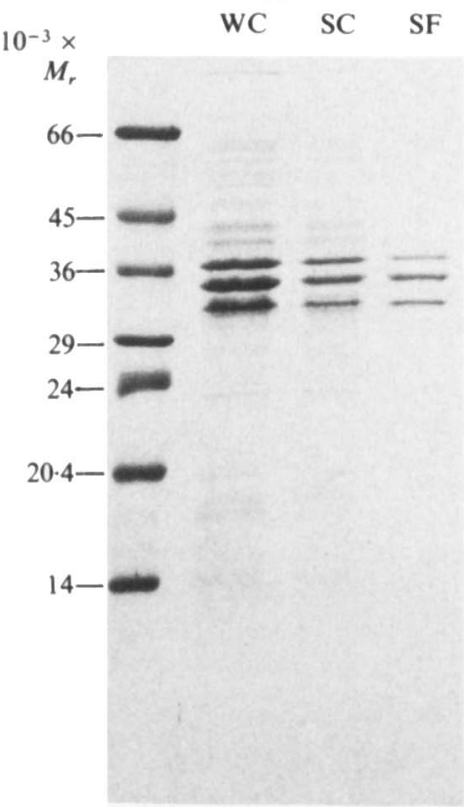

(c)

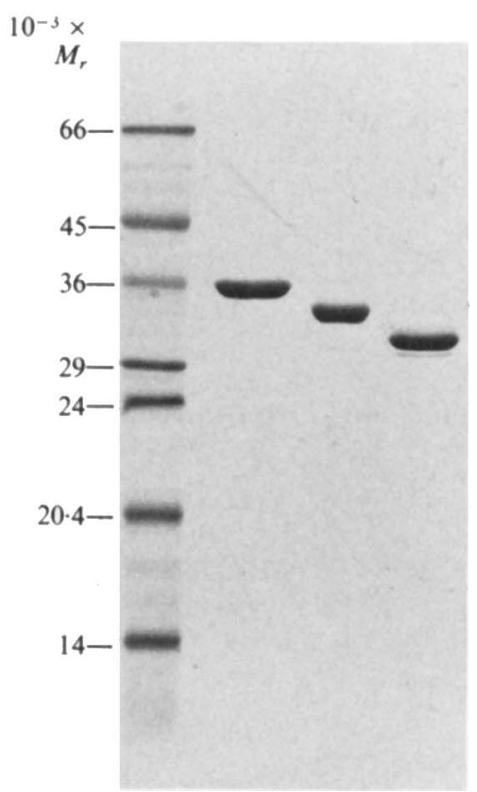

Fig. 1. Purification of three major periplasmic proteins from whole cells of $A$. radiobacter grown in continuous culture under glucose limitation $\left(D=0.045 \mathrm{~h}^{-1}\right)$. SDS-PAGE showing $(a)$ the relative concentration of the three proteins following growth under glucose and ammonia limitation (G, glucose; A, ammonia); (b) partial release of the proteins by osmotic shock (WC, whole cells; SC, shocked cells; SF, shock fluid); (c) individual proteins purified from the shock fluid using anion exchange FPLC (see Methods).

compare the polypeptide profiles of cells which had been grown under different nutrient limitations, the expectation being that any transport proteins would be maximally de-repressed only during glucose-limited growth. Using this approach it was found that $A$. radiobacter produced three proteins $\left(M_{\mathrm{r}}\right.$ values $=36500,33500$ and 30500 as judged by SDS-PAGE) at high concentrations in response to glucose limitation (Fig. 1a). Furthermore, all three proteins were partially released from the cells by osmotic shock (Fig. 1 b), and this was accompanied by a decrease of approximately $30 \%$ in the rate of glucose uptake. As this treatment did not appear to damage the cytoplasmic membrane to any extent, since 6-phosphogluconate dehydrogenase activity was not detected in the shock fluid, it was concluded that all three proteins were located in the periplasm. The three proteins were purified to near homogeneity from the shock fluid using anion exchange FPLC (Fig. 1c), and their sizes were estimated using gel filtration FPLC $\left(M_{\mathrm{r}}=44000,38000\right.$ and 36000$)$. These values, which were slightly higher than the estimates obtained using SDS-PAGE, suggest that all three proteins exist as monomers.

Equilibrium dialysis showed that only the larger two proteins were able to bind glucose and these are referred to hereafter as GBP1 $\left(M_{\mathrm{r}}=36500\right)$ and GBP2 $\left(M_{\mathrm{r}}=33500\right)$. Binding isotherms indicated that both proteins contained a single glucose binding site, but GBP2 $\left(K_{\mathrm{D}}=0.07 \mu \mathrm{M}\right)$ displayed a higher affinity for glucose than GBP1 $\left(K_{\mathrm{D}}=0.23 \mu \mathrm{M}\right)$ (Fig. 2). Competitive binding assays revealed that GBP1 and GBP2 also differed in their capacity to discriminate between certain glucose analogues (Table 1). $\alpha-1-O$-Methyl-D-glucose, 3-Omethyl-D-glucose and 2-deoxy-D-glucose did not affect the binding of glucose to either GBP1 or GBP2 and also failed to reduce significantly the rate of glucose uptake by whole cells of $A$. radiobacter (see above). By contrast, analogues which differed from glucose in having alternative substituents at C-6 (i.e. 6-deoxy-D-glucose and 6-chloro-6-deoxy-D-glucose), or in lacking C-6 altogether (i.e. D-xylose), significantly reduced the amount of $\left[{ }^{14} \mathrm{Clglucose}\right.$ that bound to both 


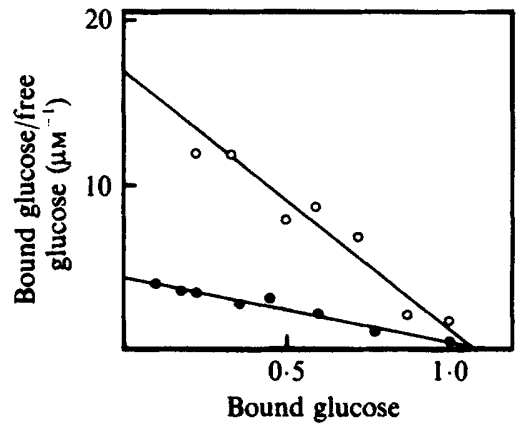

Fig. 2. Scatchard plots for the binding of glucose to two proteins released from whole cells of $A$. radiobacter by osmotic shock. The binding of $\left[{ }^{14} \mathrm{C}\right.$ glucose to pure samples of $\mathrm{GBP} 1\left(M_{\mathrm{r}}=36500\right)(O)$ and GBP2 $\left(M_{\mathrm{r}}=33500\right)(O)$ was measured using equilibrium dialysis as described in Methods. The amount of glucose bound [ $\mathrm{nmol}$ (nmol protein) ${ }^{-1}$ ] was divided by the free concentration of glucose $(\mu \mathrm{M})$ and plotted against the amount of glucose bound according to the method of Scatchard (1949). $K_{\mathrm{D}}$ values were obtained from the slopes of the plots. The intercepts on the abscissa give the stoichiometry of binding.

Table 1. Effect of glucose analogues on the binding of $\left[{ }^{14} \mathrm{Clglucose}\right.$ to GBP1 and GBP2

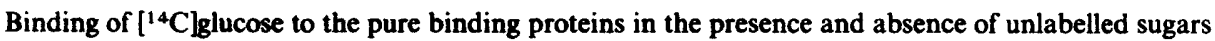
was measured using equilibrium dialysis as described in Methods.

Addition

None (control)

$\alpha-1-O$-Methyl-D-glucose

3-O-Methyl-D-glucose

2-Deoxy-D-glucose

D-Fucose

D-Galactose

6-Deoxy-D-glucose

6-Chloro-6-deoxy-D-glucose

D-Xylose

D-Glucose

\begin{tabular}{|c|c|}
\hline GBP1 & GBP2 \\
\hline 100 & 100 \\
\hline 99 & 104 \\
\hline 100 & 103 \\
\hline 96 & 98 \\
\hline 31 & 99 \\
\hline 2 & 99 \\
\hline 51 & 0 \\
\hline 0 & 60 \\
\hline 72 & 2 \\
\hline 4 & 4 \\
\hline
\end{tabular}

GBP1 and GBP2. However, 6-deoxy-D-glucose and D-xylose were much more effective with GBP2 than GBP1, whereas the converse was found to be the case for 6-chloro-6-deoxy-Dglucose. D-Galactose and D-fucose (6-deoxy-D-galactose) were only effective with GBP1, thus indicating that the configuration at $\mathrm{C}-4$ is important in determining whether a sugar can compete effectively with glucose for GBP2. The function of the third periplasmic protein $\left(M_{\mathrm{r}}=30500\right)$ is as yet unclear. However, it seems likely that it is also a periplasmic substratebinding protein, and for the purposes of this work it will be referred to as BP3.

The possibility that the three proteins might be derived from a common precursor (e.g. as a result of specific proteolytic cleavage in the periplasm) was investigated by pulse-labelling experiments using $\mathrm{L}-\left[{ }^{35}\right.$ S $]$ methionine. The results showed that the kinetics of labelling of the three proteins were inconsistent with any possible precursor-product relationship.

Variations in the concentrations of periplasmic glucose-binding proteins during growth of A. radiobacter in continuous culture under glucose limitation at a dilution rate of $0.045 h^{-1}$

The glucose uptake rates of approximately $55 \mathrm{nmol} \mathrm{min}^{-1}(\mathrm{mg} \text { dry wt})^{-1}$ reported above for whole cells of $A$. radiobacter grown under glucose limitation $\left(D=0.045 \mathrm{~h}^{-1}\right)$ were for cultures 


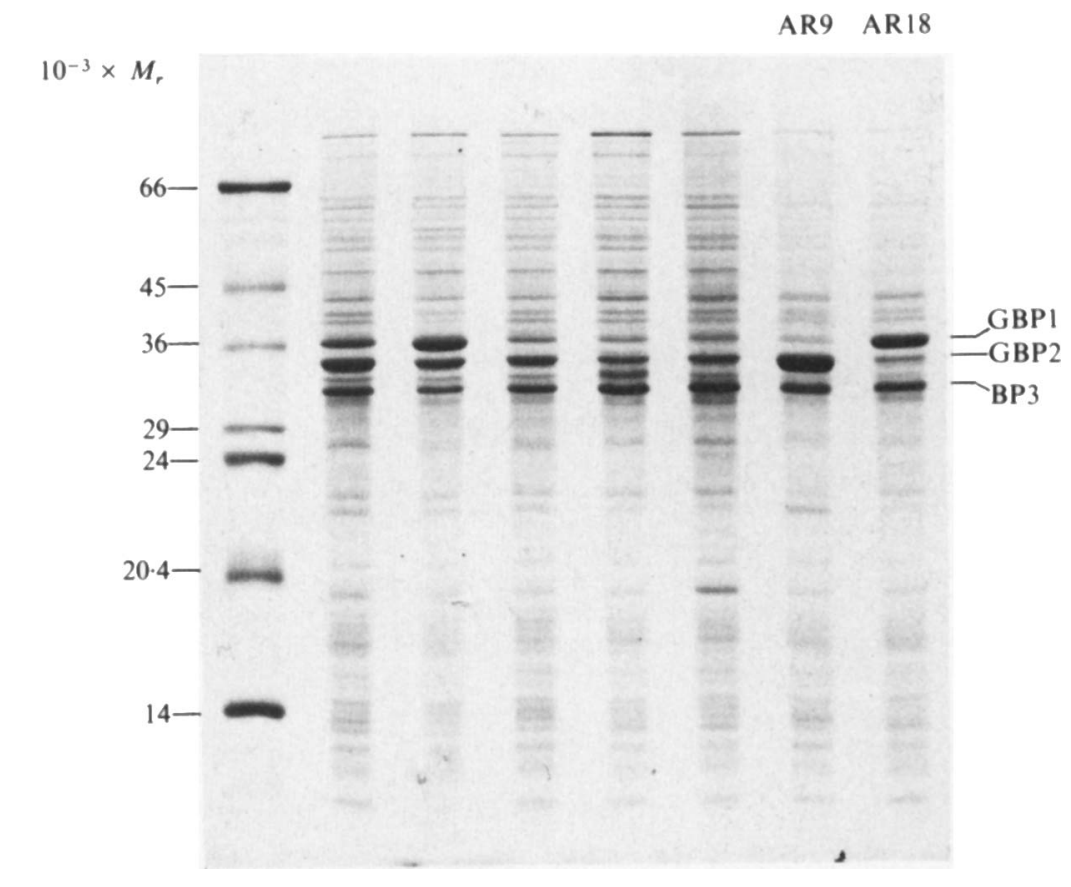

Fig. 3. SDS-PAGE showing the variations in the concentrations of GBP1, GBP2 and BP3 in whole cells of $A$. radiobacter taken from several different cultures growing under glucose limitation $\left(0-045 \mathrm{~h}^{-1}\right)$. Tracks labelled AR9 and AR18 show the polypeptide profiles of two new strains of $A$. radiobacter, the isolation of which is described in the text.

that had been grown under these conditions for at least $\mathbf{2 0}$ generations. It was subsequently found that cultures which had been grown under glucose limitation for shorter periods $(<10$

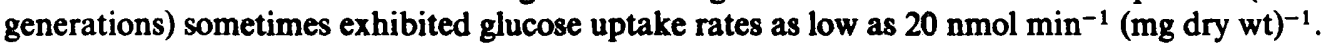
When the polypeptide profiles of cells having different glucose uptake rates were compared using SDS-PAGE it was found that both the absolute and relative concentrations of GBP1 and GBP2 varied significantly between different cultures, but the concentrations of BP3 remained relatively constant (Fig. 3). Furthermore, there was a clear correlation between the glucose uptake rates of cells from different glucose-limited cultures and the total concentration of GBP1 plus GBP2, but not BP3 (Fig. 4). This relationship confirmed that GBP1 and GBP2 both played a role in the uptake of glucose by $A$. radiobacter during growth in continuous culture under glucose limitation, although at this stage it was not clear why the organism produced two distinct glucose-binding proteins, the levels of expression of which varied between different cultures.

It was subsequently noted, however, that the concentrations of both GBP1 and GBP2 (but not BP3) both increased when the organism was grown in continuous culture under glucose limitation over a long period, but GBPl eventually predominated (Fig. 5). This observation suggested that the selective pressures imposed during an extended period of glucose-limited growth (i.e. during growth at extremely low ambient concentrations of glucose) favoured the growth of strains of $A$. radiobacter that contained higher concentrations of the two glucose binding proteins than were present in the parent organism and which were therefore capable of taking up glucose at higher rates in situ. 


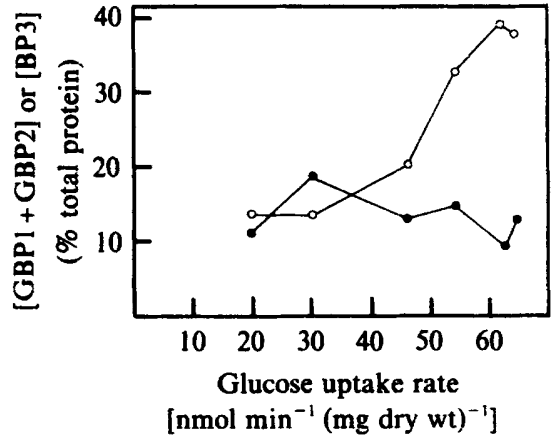

Fig. 4. Relationship between the glucose uptake capacity of whole cells of $A$. radiobacter grown in continuous culture under glucose limitation $\left(D=0.045 \mathrm{~h}^{-1}\right)$ and the concentrations of GBP1, GBP2 and BP3. Samples were withdrawn from different cultures and the glucose uptake capacity of the cells was measured using [ ${ }^{14} \mathrm{C}$ glucose. Cellular proteins were then separated using SDS-PAGE, and the concentrations of GBP1, GBP2 and BP3 were determined using microdensitometry and expressed as a percentage of the total cell protein. The abundance of GBP1 plus GBP2 $(O)$ and BP3 $(O)$ was then plotted against the glucose uptake rate.

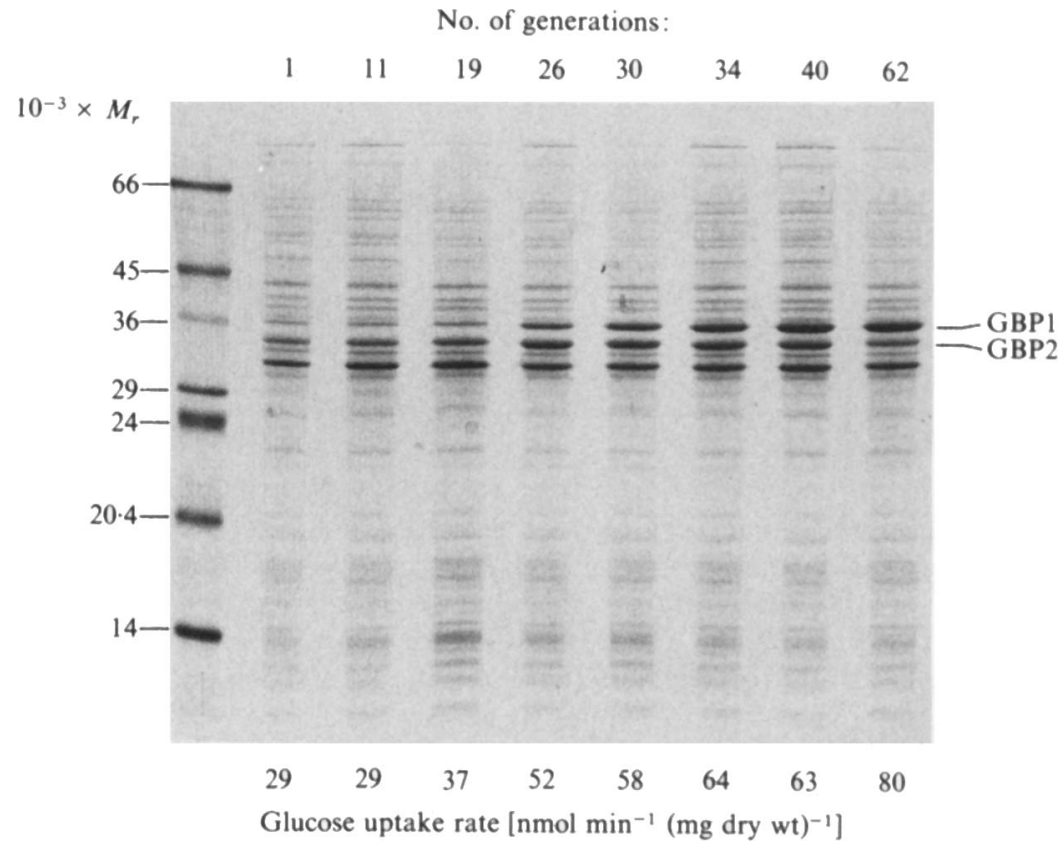

Fig. 5. SDS-PAGE showing changes in the concentrations of GBP1 and GBP2 following prolonged growth of $A$. radiobacter under glucose limitation $\left(D=0.045 \mathrm{~h}^{-1}\right)$. Samples were withdrawn from the culture at intervals and the polypeptide profiles of the cells were examined using SDS-PAGE. Numbers above individual tracks indicate the number of generation times between the onset of glucose limitation and the time of sampling. Glucose uptake rates are given below each track.

Isolation and characterization of different strains of $A$. radiobacter selected during growth under glucose limitation

In order to investigate whether transport systems involving the two glucose-binding proteins were becoming de-repressed simultaneously throughout the entire bacterial population in the 
Table 2. Effect of glucose analogues on the uptake of $\left[{ }^{14} \mathrm{C}\right]$ glucose by $A$. radiobacter strains $A R 18$ and $A R 9$ grown in continuous culture under glucose limitation $\left(D=0.45 h^{-1}\right)$

Strains AR18 and AR9, which contained high concentrations of GBP1 and GBP2 respectively, were isolated from a glucose-limited culture of $A$. radiobacter as described in the text. Uptake of $\left[{ }^{14} \mathrm{C}\right]$ glucose $(250 \mu \mathrm{M})$ was measured as described in Methods. Unlabelled sugars $(10 \mathrm{mM})$ were present in the assays

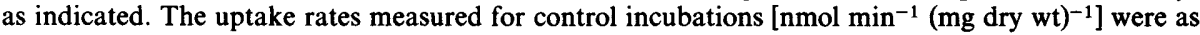
follows: AR18, 72; AR9, 63, ND, Not determined.

Addition

None (control) $\alpha-1-O$-Methyl-D-glucose

3-O-Methyl-D-glucose

2-Deoxy-D-glucose

D-Fucose

D-Galactose

6-Deoxy-D-glucose

6-Chloro-6-deoxy-D-glucose

D-Xylose

D-Glucose

\begin{tabular}{|c|c|}
\hline \multicolumn{2}{|c|}{$\begin{array}{l}\text { Glucose uptake rate } \\
(\% \text { control value) }\end{array}$} \\
\hline Strain AR18 & Strain AR9 \\
\hline 100 & 100 \\
\hline 111 & 99 \\
\hline 111 & 99 \\
\hline 93 & 71 \\
\hline 18 & 68 \\
\hline 8 & 75 \\
\hline 27 & 11 \\
\hline 8 & 33 \\
\hline 64 & ND \\
\hline 4 & 4 \\
\hline
\end{tabular}

chemostat, a sample was withdrawn from a glucose-limited culture that was fully de-repressed with respect to glucose uptake $\left[64 \mathrm{nmol} \mathrm{min}^{-1}\left(\mathrm{mg} \mathrm{dry} \mathrm{wt}^{-1}\right]\right.$ and the cells were plated out on a solid medium containing glucose as sole carbon source. Twenty-three colonies were then picked at random and used to inoculate vials containing $3 \mathrm{ml}$ glucose-minimal medium. The cultures were grown at $30^{\circ} \mathrm{C}$ at $\mu_{\max }$ until the glucose was exhausted (final cell density $=0.5 \mathrm{mg}$ dry wt $\mathrm{ml}^{-1}$ ), after which time the polypeptide profiles of the cells were examined using SDS-PAGE. Two distinct phenotypes could be distinguished based on the relative concentrations of GBP1 and GBP2. Cells originating from 11 of the colonies contained predominantly GBP1, whilst GBP2 was the most abundant in cells derived from the remaining colonies, although GBP1 was still discernible. The phenotypes appeared to be stable as no change in the protein profiles was observed when individual isolates were subjected to two further rounds of colony selection followed by growth in liquid culture. These observations suggested that $A$. radiobacter responded to prolonged growth under glucose limitation by segregating into different populations in which GBP1 and GBP2 were differentially expressed.

Two isolates representative of the different phenotypes were characterized further, viz. AR9 and AR18, in which GBP2 and GBP1 were respectively the predominant glucose-binding proteins. When single colonies of strains AR9 and AR18 were grown in continuous culture under glucose limitation $\left(0.045 \mathrm{~h}^{-1}\right)$ they exhibited glucose uptake rates of 63 and $74 \mathrm{nmol} \mathrm{min}^{-1}$ (mg dry wt) $)^{-1}$ respectively as soon as the steady state was attained, i.e. without a further period of selection. SDS-PAGE of whole cell suspensions, and FPLC analysis of shock fluids prepared from the two strains, revealed that they had retained the capacity to produce both of the glucosebinding proteins, albeit in vastly different amounts; GBP2 was the major glucose-binding protein produced by strain AR9 and GBP1 was the most abundant in strain AR18, but both strains produced similar amounts of BP3 (see also Fig. 3). This finding suggested that prolonged growth under glucose limitation had resulted in the selection of strains of $A$. radiobacter in which either (but not both) of the glucose-binding proteins were further de-repressed relative to the parent organism.

Unlabelled glucose analogues that reduced the extent of binding of $\left[{ }^{14} \mathrm{C}\right]$ glucose to GBP1 in vitro (Table 1) also diminished the rate of uptake of glucose by strain AR18 (Table 2) in the same rank order of potency (i.e. D-galactose $=6$-chloro-6-deoxy-D-glucose $>$ D-fucose $>6$ deoxy-D-glucose $>$ D-xylose). By comparison, the uptake of $\left[{ }^{14} \mathrm{C}\right]$ glucose by strain AR9 was much less sensitive to inhibition by a given analogue, the only exception being 6-deoxy-D- 
glucose (Table 2), which was also more effective at preventing glucose from binding to GBP2 than to GBP1 in vitro (Table 1). The results of these competition experiments were entirely consistent with the proposal that most of the glucose taken up by strain AR18 is transported via a system involving GBP1, whilst strain AR9 uses predominantly GBP2. Indeed, the results obtained with D-galactose, which abolished the binding of glucose to GBP1 in vitro but had no effect with GBP2 (Table 1), suggested that approximately $90 \%$ of the glucose taken up by strain AR 18 was transported via GBP1 compared with only $25 \%$ for strain AR9 (Table 2). 2-Deoxy-Dglucose reduced the rate of glucose uptake to a relatively small extent with both strains but had no effect on the binding of glucose to GBP1 or GBP2 in vitro, thus suggesting either that the organism may possess an additional, low-activity glucose uptake system that is as yet uncharacterized or that there are slight differences between binding and transport effects.

\section{DISCUSSION}

We have shown that three periplasmic proteins are markedly de-repressed during the growth of $A$. radiobacter in continuous culture at low dilution rate under glucose limitation. Two of these (GBP1 and GBP2) bound glucose with high affinity and are probably the binding protein components of two independent, active transport systems for glucose. Two strains of the organism were isolated which produced either GBP1 (strain AR18) or GBP2 (strain AR9), but not both proteins, in large amounts and these were used to compare the extent to which different glucose analogues inhibited glucose uptake in vivo with their capacity to prevent glucose from binding to the pure proteins in vitro. The correspondence between the two sets of measurements confirmed that both binding proteins participated in glucose transport. Pseudomonas aeruginosa also transports glucose directly by way of a binding protein system (Stinson $e$ t al., 1977), and it has been suggested that Rhizobium leguminosarum possesses two such transport systems with different substrate specificities, although the two glucose-binding proteins have not been purified and characterized (de Vries et al., 1982). From the limited number of examples available it seems possible that aerobic organisms may in general take up glucose using binding protein systems rather than the phosphotransferase systems that most often fulfil this role in both obligate and facultative anaerobes (Postma, 1986).

Recently it has been shown that mutants of $E$. coli having non-polar deletions in the malE gene (which encodes the maltose-binding protein) become competent in maltose uptake following the introduction of pure maltose-binding protein into the periplasm (Brass et al., 1983). We have been unable to use this direct approach to prove that GBP1 and GBP2 participate in glucose transport in $A$. radiobacter since the appropriate mutants are not at present available. However, the levels of expression of the two glucose-binding proteins and the potential glucose uptake capacity of the organism both increased in response to prolonged growth under glucose limitation, thus providing additional evidence that these proteins are involved in glucose transport. The function of BP3 is uncertain; it is not involved in glucose transport, since it does not bind glucose, and is apparently de-repressed as a result of a general phenotypic response to carbon limitation (Harder \& Dijkhuizen, 1983) rather than to low concentrations of glucose per se.

It has been predicted on theoretical grounds that novel strains emerge during nutrient-limited growth since they can grow faster than the average population at a given dilution rate because they exhibit an increased $\mu_{\max }$ (the standing concentration of the growth-limiting substrate remains unchanged) and/or a decreased $K_{\mathrm{s}}$ (the standing concentration of the growth-limiting nutrient falls) (Harder et al., 1977). Rutgers et al. (1987) recently reported that Klebsiella pneumoniae responds to prolonged glucose limitation by increasing $\mu_{\max }$ and decreasing $K_{\mathrm{s}}$ simultaneously, but the biochemical basis for the adaptation was not pinpointed.

We have apparently observed a similar long-term adaptation to nutrient limitation with $A$. radiobacter, except that in this case the organism responds to prolonged glucose limitation by segregating into two strains in which one or other, but not both, of the glucose transport systems are hyperproduced relative to the parent organism. This adaptation presumably enables the strains to outcompete the parent organism by taking up glucose at higher rates when the 
standing concentration of glucose in the chemostat is very low, as will be the case during glucoselimited growth at low dilution rate. The two $A$. radiobacter strains containing mainly GBPI or GBP2 exhibited similar rates of glucose uptake (indicating similar $V_{\max }$ values) and also appeared to co-exist within the chemostat for long periods of time, thus indicating that the $K_{m}$ values of the intact transport systems (i.e. the glucose-binding proteins plus the presumed membrane components) must be similar in vivo in spite of the observation that GBP2 showed an approximately threefold greater affinity for glucose than GBP1 in vitro.

The observation that very large amounts of the glucose-binding proteins (up to approximately $40 \%$ of the total cell protein) are synthesized during glucose-limited growth is consistent with suggestions that binding proteins play an important role in sequestering substrates (Ames, 1986) and/or facilitating their transfer across the highly viscous periplasm (Brass et al., 1986) when the standing concentration of the carbon substrate is very low.

The present work has demonstrated that the selective pressures imposed on $A$. radiobacter during prolonged growth under glucose limitation result in the simultaneous emergence of strains which have adapted to the environment in different ways. It seems reasonable to assume that other organisms respond similarly, in which case it may often be incorrect to assume that the transport system used to take up the growth-limiting substrate is the same at the outset of nutrient-limited growth as at the end (see also Collins et al., 1976). It is not clear why A. radiobacter possesses two glucose uptake systems, although it is not unusual for an organism to take up a given sugar by more than one route, but the possibility that one or both of the binding proteins may be involved in the transport of other sugars is currently being investigated.

In the following paper (Cornish et al., 1988) we investigate the relationship between glucose transport and succinoglucan production in $A$. radiobacter.

The authors are indebted to John Linton for useful discussions, and to Shell Research for financial support.

\section{REFERENCES}

AMES, G. F.-L. (1986). Bacterial periplasmic transport systems: structure, mechanism, and evolution. $A n$ nual Review of Biochemistry 55, 397-425.

Beardsmore, A. J., APerghis, P. N. G. \& Quayle, J. R. (1982). Characterization of the assimilatory and dissimilatory pathways of carbon metabolism during growth of Methylophilus methylotrophus on methanol. Journal of General Microbiology 128, 14231439.

Brass, J. M., Ermann, U. \& Burau, B. (1983). Reconstitution of maltose transport in Escherichia coli : conditions affecting import of maltose-binding protein into calcium-treated cells of maltose regulon mutants. Journal of Bacteriology 155, 97-106.

Brass, M., Higgins, C. F., Foley, M., Rugman, P. A., BirminghaM, J. \& Garland, P. B. (1986). Lateral diffusion of proteins in the periplasm of Escherichia coli. Journal of Bacteriology 165, 787-794.

Collins, S. H., JARVIS, A. W., LINDSAY, R. J. \& Hamiton, W. A. (1976). Proton movements coupled to lactate and alanine in Escherichia coli: isolation of mutants with altered stoichiometry in alanine transport. Journal of Bacteriology 126, 1232-1244.

CORnish, A., Linton, J. D. \& JoNEs, C. W. (1987). The effect of growth conditions on the respiratory system of a succinoglucan-producing strain of Agrobacterium radiobacter. Journal of General Microbiology 133, 2971-2978.

Cornish, A., Greenwood, J. A. \& Jones, C. W. (1988). The relationship between glucose transport and the production of succinoglucan exopolysac- charide by Agrobacterium radiobacter. Journal of General Microbiology 134, 3111-3122.

DuRhaM, D. R. \& Pribis, P. V., JR (1982). Fractionation and characterization of the phosphoenolpyruvate :fructose 1-phosphotransferase system from Pseudomonas aeruginosa. Journal of Bacteriology 149, 534-541.

HArder, W. \& Durhutzen, L. (1983). Physiological responses to nutrient limitation. Ammual Review of Microbiology 37, 1-23.

HARder, W., KUENBN, J. G. \& Matin, A. (1977). Microbial selection in continuous culture. Journal of Applied Bacteriology 43, 1-24.

Henderson, P. J. F. (1986). Active transport of sugars into Escherichia coli. In Carbohydrate Metabolism in Cultured Cells, pp. 409-460. Edited by M. J. Morgan. New York: Plenum Press.

Henderson, P. J. F. \& Macpherson, A. J. S. (1986). Assay, genetics, proteins and reconstitution of proton-linked galactose, arabinose and xylose transport systems of Escherichia coli. Methods in Enzymology 125, 387-429.

LAEMMLI, U. K. (1970). Cleavage of structural proteins during the assembly of the head of bacterophage T4. Nature, London 227, 680-685.

LINTON, J. D., WOODaRD, S. \& Gouldney, D. G. (1986). The consequence of stimulating glucose dehydrogenase activity by the addition of $P Q Q$ on metabolite production by Agrobacterium radiobacter NCIB 11883. Applied Microbiology and Biotechnology 25, 357-361. 
Linton, J. D., Evans, M. W., Jones, D. S. \& GouLDNEY, D. G. (1987). Exocellular succinoglucan production by Agrobacterium radiobacter NCIB 11883. Journal of General Microbiology 133, 29612969.

MIDGLEY, M. \& DAWES, E. A. (1973). The regulation of transport of glucose and methyl $\alpha$-glucoside in Pseudomonas aeruginosa. Biochemical Journal 132, 141-154.

NBu, H. C. Heppel, L. A. (1965). The release of enzymes from Escherichia coli by osmotic shock and during the formation of sphaeroplasts. Journal of Biological Chemistry 240, 3685-3692.

Postma, P. W. (1986). The bacterial phosphoenolpyruvate : sugar phosphotransferase system of Escherichia coli and Salmonella typhimurium. In Carbohydrate Metabolism in Cultured Cells, pp. 367-408. Edited by M. J. Morgan. New York: Plenum Press. QUILTER, J. A. \& JONES, C. W. (1984). The organisation of methanol dehydrogenase and $c$-type cytochromes on the respiratory membrane of Methylophilus methylotrophus. FEBS Letters 174, 167172.

RoberTs, B. K., MidGley, M. \& DAWES, E. A. (1973). The metabolism of 2-oxogluconate by Pseudomonas aeruginosa. Journal of General Microbiology 78, 319329.
Rutgers, M., Telxera de Matros, M. J., Postma, P. W. \& VAN DAM, K. (1987). Establishment of the steady state in glucose-limited chemostat cultures of Klebsiella pneumoniae. Journal of General Microbiology 133, 445-451.

SCATCHARD, G. (1949). The attractions of proteins for small molecules and ions. Annals of the New York Academy of Sciences 51, 660-672.

Stinson, M. W., Cohen, M. A. \& Merrick, J. M. (1977). Purification and properties of the periplasamic glucose-binding protein of Pseudomonas aeruginosa. Journal of Bacteriology 131, 672-681.

De VRies, G. E., van Brussel, A. N. \& Quispel, A. (1982). Mechanism and regulation of glucose transport in Rhizobium leguminosarum. Journal of Bacteriology 149, 872-879.

Weber, K. \& Osborne, M. (1975). Proteins and sodium dodecyl sulphate: molecular weight determinations on polyacrylamide gels and related procedures. In The Proteins I, 3rd edn, pp. 179-223. Edited by $H$. Neurath \& R. L. Hill. London: Academic Press.

Whiting, P. H., Midgley, M. \& DAWEs, E. A. (1976). The role of glucose limitation in the regulation of the transport of glucose, gluconate and 2-oxogluconate, and of glucose metabolism in Pseudomonas aeruginosa. Journal of General Microbiology 92, 304-310. 